\title{
CORTICAL BONE SCREWS CONSTRUCTIVE CHARACTERISTICS - A COMPARATIVE STUDY
}

\author{
ANDREA T. LUGAS ${ }^{1,2}$, DOMENICO C. ALOJ ${ }^{3}$, DANIELE SANTORO ${ }^{4}$, VITTORIA CIVILINII ${ }^{1,2}$, \\ SIMONE BORRELLI ${ }^{1,2}$ \& CRISTINA BIGNARDI ${ }^{1,2}$ \\ ${ }^{1}$ Department of Mechanical and Aerospace Engineering, Politecnico di Torino, 10129 Turin, Italy. \\ ${ }^{2}$ Polito ${ }^{\mathrm{BIO}}$ Med Lab, Politecnico di Torino, 10129 Turin, Italy. \\ ${ }^{3}$ Orthopedics and Traumatology Complex Structure AsIVC, Sant'Andrea Hospital, 13100, Vercelli, Italy. \\ ${ }^{4}$ Orthopedics and Traumatology Complex Operating Unit, I University Orthopedic Clinic, 10126 Turin, Italy.
}

\begin{abstract}
Osteosynthesis is a surgical technique for the treatment of skeletal fractures through the implant of mechanical devices, such as plates and screws, in order to stabilize and fix the injured skeletal segment. It is preferred to the conservative treatment when the fracture requires immediate surgical correction or when, blocking the joints, degenerative changes could occur. Bone screws have different shapes and sizes depending on the intended use. In this study, six types of cortical bone screws were tested to determine the torque transmitted to the bone during the insertion. One Ti6Al4V tapered $(\varnothing 6 \mathrm{~mm})$ and five AISI 316L stainless steel - two straight ( $\varnothing 4$ and $6 \mathrm{~mm})$ and three tapered $(\varnothing 4,5$, and $6 \mathrm{~mm})$ - screws were used during the tests. Screws have been screwed into Sawbones (Sawbones ${ }^{\circledR}$ Pacific Research Laboratories, Inc., Vashon, USA) solid foam-type cylinders (external diameter $30 \mathrm{~mm}$ and thickness $3.5 \mathrm{~mm}$ ) simulating the cortical bone diaphysis. Each of the 26 screws tested was inserted in a Sawbone cylinder five times, in five previously drawn equally spaced points, without any pilot holes. The experiment design was based on the ASTM standard for medical bone screws; two experienced orthopedic surgeons performed the insertions and removals of the screws using a hand-drill at $1 \mathrm{rev} / \mathrm{s}$, aided by a metronome, and the torque was measured with a torsiometer throughout the tests. The mean and maximum torque resulted to be higher for larger diameter screws. Considering the same diameter, tapered screws showed a higher torque required for the extraction, which indicates stronger retention. However, in some cases, the Sawbones cylinder was fractured during the insertion of screws with a $6 \mathrm{~mm}$ diameter. Therefore, the use of medium-size tapered screws might be the most advisable compromise.
\end{abstract}

Keywords: Cortical bone screws, Diameter, Extraction torque, Insertion torque, Shape.

\section{INTRODUCTION}

Nowadays, the use of plating systems and screw fixation has become an established treatment for bone fractures, and the screw-bone interface is the weakest part of the implant. The success of the fixation is therefore related to the stability of the screw. The initial fixation of the screws can be assessed by evaluating the maximum torque during the insertion [1-3], which depends on numerous factors, including the bone mineral density, the design of the screw, and its dimensions [4-7]. Low insertional torque can cause poor compressive force between the plate and the bone [8]. On the other hand, excessive insertional torque can lead to the stripping of the screw, affecting its primary stability [9-11]. High insertional torque is also related to a greater inflammatory response of the tissue near the implant, which can lead to the failure of the implant as well [12]. Therefore, a compromise must be found to ensure fixation stability and avoid screw stripping and excessive tissue damage. Clinically, orthopedic surgeons tighten the screws until reaching the optimal stopping torque by subjective feel basing on their experience [5, 13]. Many studies investigated the optimal insertional 
force for the screw stability as a percentage of the maximum torque, but no consensus has been attained [14]. Using an experimental setup based on the ASTM standard for medical screws (ASTM F543-07), this study evaluated and compared six types of cortical bone screws, assessing the role of screw design in the mean and maximum insertional torque values.

\section{MATERIALS AND METHODS}

In this study, six types of cortical bone screws (Table 1) were inserted into Sawbones (Sawbones® Pacific Research Laboratories, Inc., Vashon, USA) solid foam-type cylinders (external diameter $30 \mathrm{~mm}$, thickness $3.5 \mathrm{~mm}$ ) simulating the cortical bone diaphysis.

Five equally spaced points were drawn on each cylinder. No pilot holes were created, regardless of the screw's manufacturer recommendations, in order to avoid bias in the comparison between different screws. The cylinders were placed in custom-manufactured holders and constrained through two bench clamps before the tests.Two experienced orthopedic surgeons inserted 26 screws in as many cylinders by means of a hand drill (Fig. 1a), and five holes were performed with each screw, at a constant rotation speed of approximately $1 \mathrm{rev} / \mathrm{s}$, controlled with a metronome. The screws were inserted until both walls of the cylinders were perforated (Fig. 1b).

The torque value was measured and recorded during each test employing a torque digital indicator (DTR 526, Vetek Weighing AB, Väddö, Sweden) using the TDemo1 software (AEP transducers, Cogneto, Italy). The mean and maximum insertion torque was computed for each test, and the maximum extraction torque was recorded as well, for retention evaluation. In order to establish the statistical significance of the screw geometry and the inter-operator variability of the results, a statistical analysis of variance (ANOVA) was performed on the data considering the following factors: (1) maximum screw diameter $(4,5$, and $6 \mathrm{~mm}),(2)$ the screw shape (tapered and straight), and (3) the operator which performed the insertion. The analysis was performed considering both the mean and the maximum insertion torque as dependent variables, using a significant level $\alpha$ equal to 0.05 .

Table 1: Cortical bone screws. Producers: Citieffe S.R.L. (Calderara di Reno, BO, Italy) and Orthofix S.R.L. (Bussolengo, VR, Italy).

\begin{tabular}{|c|c|c|c|c|c|}
\hline Quantity & Shape & $\begin{array}{l}\text { Diameter } \\
{[\mathrm{mm}]}\end{array}$ & $\begin{array}{l}\text { Pitch } \\
{[\mathrm{mm}]}\end{array}$ & Material & Producer \\
\hline 4 & Tapered & 3 to 4 & 1.2 & $\begin{array}{l}\text { AISI316L } \\
\text { ASTM F138 }\end{array}$ & Citieffe S.R.L. \\
\hline 5 & Tapered & 4 to 5 & 1.4 & $\begin{array}{l}\text { AISI316L } \\
\text { ASTM F138 }\end{array}$ & Citieffe S.R.L. \\
\hline 4 & Tapered & 5 to 6 & 1.8 & $\begin{array}{l}\text { AISI316L } \\
\text { ASTM F138 }\end{array}$ & Citieffe S.R.L. \\
\hline 5 & Tapered & 4 to 6 & 1.4 & $\begin{array}{l}\text { Ti6Al4V } \\
\text { ASTM F136 }\end{array}$ & Citieffe S.R.L. \\
\hline 4 & Straight & 4 & 1.3 & $\begin{array}{l}\text { AISI316L } \\
\text { ASTM F138 }\end{array}$ & Orthofix S.R.L. \\
\hline 4 & Straight & 6 & 1.2 & $\begin{array}{l}\text { AISI316L } \\
\text { ASTM F138 }\end{array}$ & Orthofix S.R.L. \\
\hline
\end{tabular}




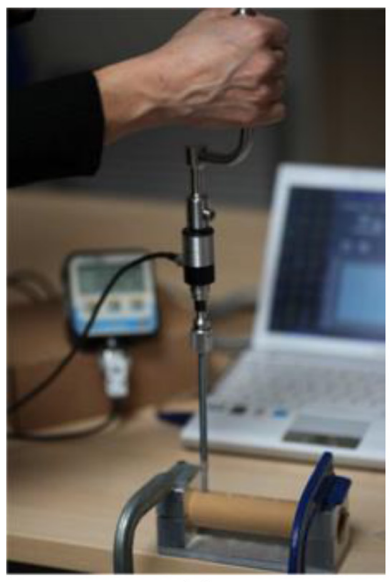

(a)

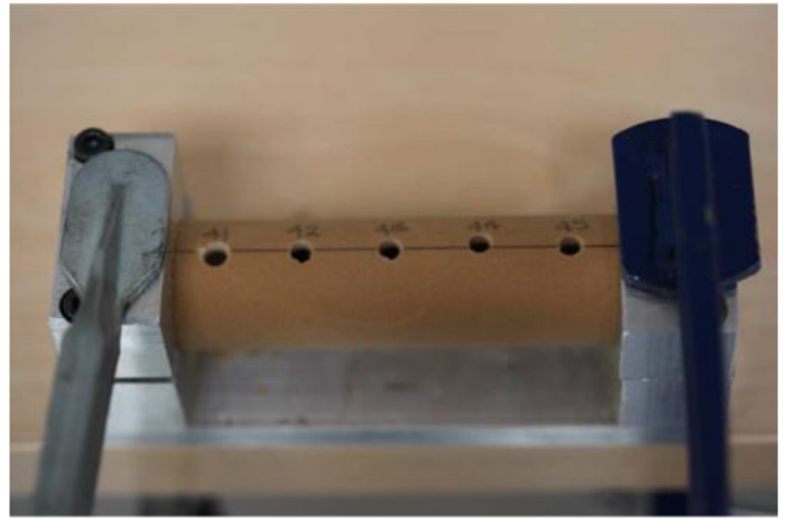

(b)

Figure 1: (a) Screw insertion, (b) holes in the cylinder simulating a cortical bone diaphysis.

\section{RESULTS}

As previously pointed out, the torque trend over time was recorded during each test. It was used to compute the torque value corresponding to the screw insertion depth following Eqn (1), as shown in Fig. 2.

$$
d=\mathrm{p} \cdot \omega \cdot \mathrm{t}
$$

- $d$ : indentation depth (mm)

- p: screw pitch (mm/round)

- $\omega$ : insertion speed (round/s)

- t: time (s)

The mean and standard deviation values of the mean and maximum insertion torque were computed for each group of tests performed by the same operator using the same type of screw. The results are shown in Fig. 3. Each label indicates the diameter of the screw - minimum and maximum diameter are indicated for tapered screws - and the operator which performed the insertion. The ANOVA highlighted the statistical significance of the differences obtained between different screws. Indeed, for the first two factors used for the analysis (i.e. the screw diameter and shape), a significance value $\mathrm{p}<0.05$ was obtained. However, no

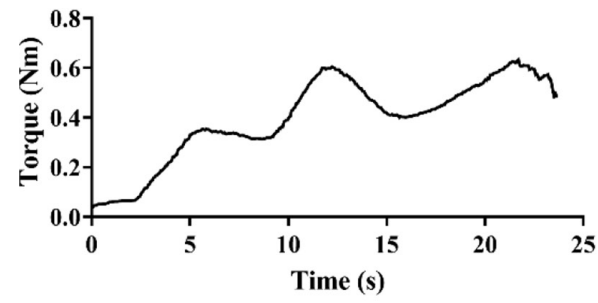

(a)

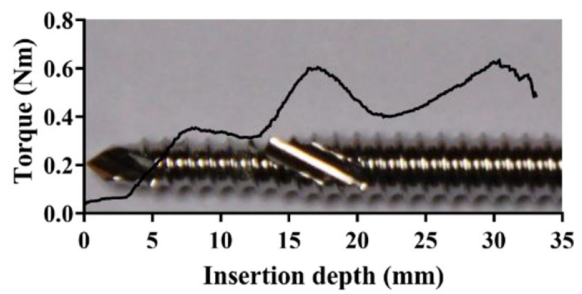

(b)

Figure 2: Torque of the 4-to-5 mm diameter screw. (a) Trend over time, (b) trend over insertion depth, superimposed to the screw profile. 
significant differences were detected between the tests performed by the two operators using screws of the same type $(\mathrm{p}>0.05)$. For these reasons, the means and standard deviations were calculated for mean and maximum insertion torque obtained with each type of screw (Fig. 4), regardless of the operator which performed the tests.

Among the screws with a $4 \mathrm{~mm}$ diameter, the straight one achieved the lowest values of insertion torque, while the most tapered (4-6 mm diameter) provided similar results compared with the 5-6 mm diameter tapered screw. Using the screws with the largest diameter (i.e. $6 \mathrm{~mm}$ ), no significant differences were detected in terms of mean torque. However, during the tests performed with the most tapered one, higher maximum torques were recorded.

The maximum torque during screw extraction was also computed for each type of screw. The results, in terms of mean value and standard deviation, are shown in Fig. 5.

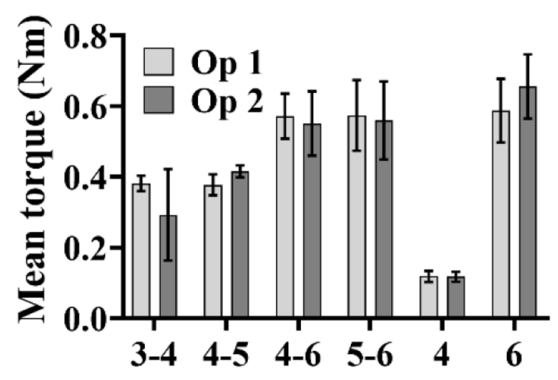

Diameter (mm)

(a)

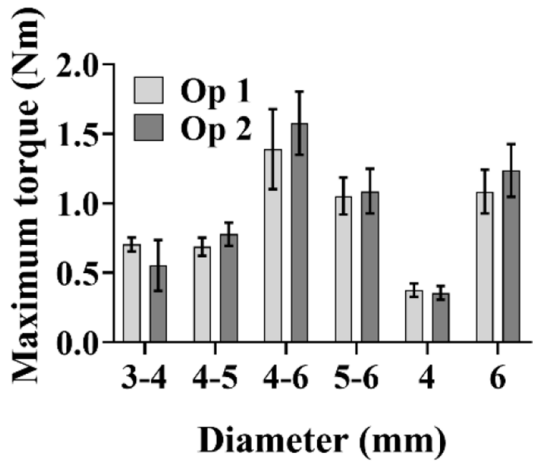

(b)

Figure 3: (a) Mean and (b) maximum torque during screw insertion. The tests were divided according to screw type and operator.

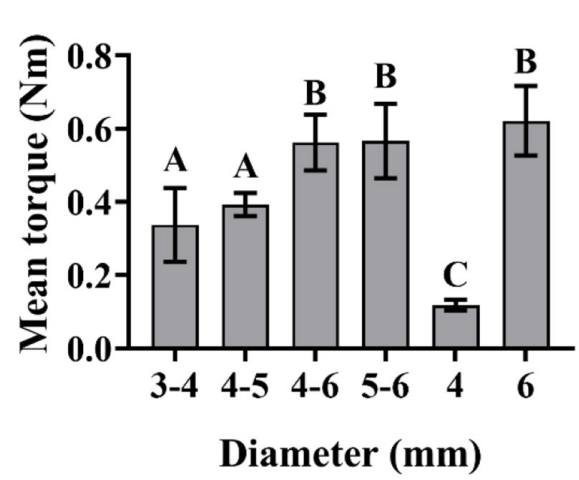

(a)

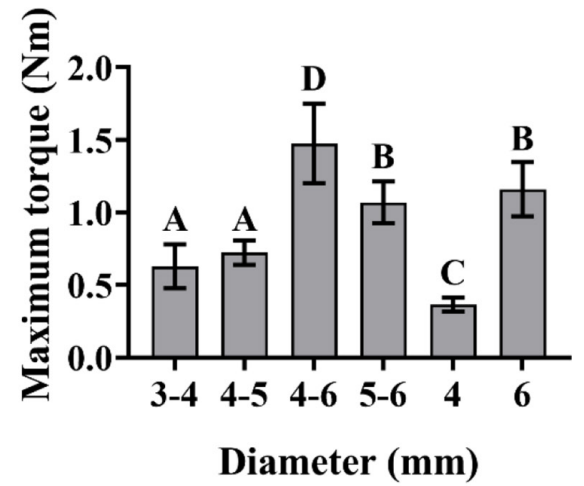

(b)

Figure 4: (a) Mean and (b) maximum torque during screw insertion. The tests were divided according to screw type, and the diameter was considered as the independent variable for the ANOVA. The letters shown above each bar represent the statistical significance of the difference between different screws (bars labeled with different letters are statistically different). 


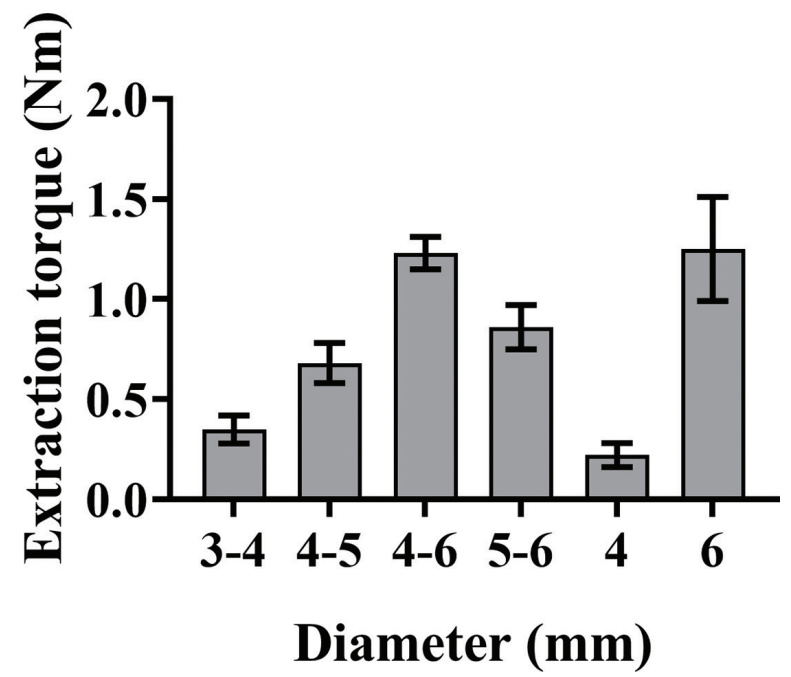

Figure 5: Mean and standard deviation of the maximum torque reached during the extraction of each type of screw.

\section{DISCUSSION}

Insertion torque is considered one of the most reliable indexes of screw stability, which is usually evaluated experimentally through the pullout strength. The inter-operator variability of the obtained torque was also investigated, and it resulted to be negligible among trained orthopedic surgeons (Fig. 2). Another important factor that influences the insertion torque and the stability of the screw is the bone quality, often measured in terms of areal bone mineral density [15]. In this study, the screws were inserted in identical synthetic cortical bone reproduction, which can be considered as a limit of the investigation, although it avoided results bias. Among the factors that were taken into consideration during this study, the influence of the screw diameter was significant, in accordance with previous findings [9]. The shape of the screw influenced the insertion torque as well, as shown in Fig. 4. Going into detail, among the screws with $4 \mathrm{~mm}$ maximum diameter, the tapered one provided a higher insertion torque. On the other hand, the shape had a lower influence with larger screws. Indeed, no significant difference was found between tapered and straight $6 \mathrm{~mm}$ screws in terms of mean insertion torque, while the maximum insertion torque obtained with the most tapered screw was significantly different from the others. The influence of the screw pitch was previously investigated by other authors, obtaining different results: in some studies, the pitch influenced the insertion torque [16], while it was not significant in other investigations [8]. In this study, the importance of screw pitch was not highlighted, which could be caused by the fact that its influence also relies on bone quality [17]. The maximum extraction torque was recorded during each test (Fig. 5). The comparison between different screws is similar to the one obtained with the maximum insertion torque, except for the 6 $\mathrm{mm}$ diameter, straight-shaped screw, which, however, was associated with the highest value of standard deviation.

\section{CONCLUSIONS}

The structural analysis of skeletal body elements and of biomechanical systems consisting of a bone element coupled to a prosthesis, an implant or a fracture synthesis device, can be 
performed both numerically and experimentally [18]. There are many examples of clinical problems, which have moved from a qualitative assessment to a quantitative evaluation thanks to the respective modelling [19-39] or to the application of classical experimental methods of structural analysis to the evaluation of the efficacy of procedures or surgical techniques [40-75] or to the evaluation of the mechanical characteristics of the materials used at different scales of investigation [76-92]. Moreover, the structural analysis of medical devices and biological tissues is strictly connected with the in-vivo behavior of their interaction [93, 94].

However, each approach has its own limitations: numerical models can be very complex and consequently need to be validated; experimental tests cannot faithfully reproduce the real conditions and they require simplifications, in most cases. On the basis of these assumptions, both approaches still remain necessary and, in most cases, complementary.

This study aimed to compare the insertion torque obtained with different cortical screws, focusing on their constructive differences (i.e. the shape, the maximum diameter, and the pitch). In light of the results, the authors would conclude that the maximum value of the insertion torque is more capable to highlight the influence of the screw taper rather than the mean value. Moreover, using screws with $6 \mathrm{~mm}$ diameter and tapered shape, the specimen underwent unexpected fracture several times, confirming that an excessive insertion torque may cause implant failure. Therefore, a nonexcessive diameter combined with a tapered shape could be the most advisable compromise.

\section{ACKNOWLEDGEMENTS}

Thanks to Citieffe S.R.L for funding the research.

\section{REFERENCES}

[1] Erani, P. \& Baleani, M., Achievable accuracy of hip screw holding power estimation by insertion torque measurement. Clinical Biomechanics, 52, pp. 57-65, 2018. https://doi. org/10.1016/j.clinbiomech.2018.01.010

[2] Basmajian, H.G., Liu, J.N., Scudday, T., Campbell, S.T. \& Amin, N.H., Kirschner wire prepared pilot holes improve screw pullout strength in synthetic osteoporotic-type bone. Journal of Clinical Orthopaedics and Trauma, 11, pp. 100-104, 2020. https:// doi.org/10.1016/j.jcot.2019.08.015

[3] Tepedino, M., Masedu, F. \& Chimenti, C., Comparative evaluation of insertion torque and mechanical stability for self-tapping and self-drilling orthodontic miniscrews - an in vitro study. Head \& Face Medicine, 13(1), pp. 10, 2017. https://doi.org/10.1186/ s13005-017-0143-3

[4] Ab-Lazid, R., Perilli, E., Ryan, M.K., Costi, J.J. \& Reynolds, K.J., Does cancellous screw insertion torque depend on bone mineral density and/or microarchitecture $\alpha$. Journal of Biomechanics, 47(2), pp. 347-353, 2014. https://doi.org/10.1016/j. jbiomech.2013.11.030

[5] Tsuji, M., Crookshank, M., Olsen, M., Schemitsch, E.H. \& Zdero, R., The biomechanical effect of artificial and human bone density on stopping and stripping torque during screw insertion. Journal of the Mechanical Behavior of Biomedical Materials, 22, pp. 146-156, 2013. https://doi.org/10.1016/j.jmbbm.2013.03.006

[6] Kunkel, K.A.R., Suber, J.T., Gerard, P.D. \& Kowaleski, M.P., Effect of pilot hole diameter and tapping on insertion torque and axial pullout strength of 4.0-mm cancellous bone screws. American Journal of Veterinary Research, 72(12), pp. 1660-1665, 2011. https://doi.org/10.2460/ajvr.72.12.1660 
[7] Koistinen, A., Santavirta, S.S., Kröger, H. \& Lappalainen, R., Effect of bone mineral density and amorphous diamond coatings on insertion torque of bone screws. Biomaterials, 26(28), pp. 5687-5694, 2005. https://doi.org/10.1016/j.biomaterials.2005.02.003

[8] Addevico, F., Morandi, M., Scaglione, M. \& Solitro, G.F., Screw insertion torque as parameter to judge the fixation. Assessment of torque and pull-out strength in different bone densities and screw-pitches. Clinical Biomechanics, 72(December 2019), pp. 130-135, 2020. https://doi.org/10.1016/j.clinbiomech.2019.12.004

[9] McAndrew, C.M., Agarwalla, A., Abraham, A.C., Feuchtbaum, E., Ricci, W.M. \& Tang, S.Y., Local bone quality measurements correlates with maximum screw torque at the femoral diaphysis. Clinical Biomechanics, 52, pp. 95-99, 2018. https://doi. org/10.1016/j.clinbiomech.2018.01.016

[10] Sunagawa-Kojima, H., Ohtani, J., Kaku, M., Tsubamoto, N., Ishikawa, E., Tanne, K. \& Tanimoto, K., Histomorphometric evaluation of cortical bone surrounding mini-screw: Why is the insertion torque critical for primary stability? Biomedical Research, 29(14), pp. 3028-3033, 2018. https://doi.org/10.4066/biomedicalresearch.29-18-892

[11] Fletcher, J.W.A., Ehrhardt, B., MacLeod, A., Whitehouse, M.R., Gill, H. \& Preatoni, E., Non-locking screw insertion: No benefit seen if tightness exceeds $80 \%$ of the maximum torque. Clinical Biomechanics, 70(July), pp. 40-45, 2019. https://doi.org/10.1016/j. clinbiomech.2019.07.009

[12] Togni, F., Baras, F., Ribas, M.D.O. \& Taha, M.O., Histomorphometric analysis of bone tissue repair in rabbits after insertion of titanium screws under different torque. Acta Cirurgica Brasileira, 26(4), pp. 261-266, 2011. https://doi.org/10.1590/s010286502011000400003

[13] Reynolds, K.J., Cleek, T.M., Mohtar, A.A. \& Hearn, T.C., Predicting cancellous bone failure during screw insertion. Journal of Biomechanics, 46(6), pp. 1207-1210, 2013. https://doi.org/10.1016/j.jbiomech.2013.01.021

[14] Weidling, M., Oefner, C., Schoenfelder, S. \& Heyde, C.E., A novel parameter for the prediction of pedicle screw fixation in cancellous bone - A biomechanical study on synthetic foam. Medical Engineering \& Physics, 79, pp. 44-51, 2020. https://doi. org/10.1016/j.medengphy.2020.03.001

[15] Ab-Lazid, R., Perilli, E., Ryan, M.K., Costi, J.J. \& Reynolds, K.J., Pullout strength of cancellous screws in human femoral heads depends on applied insertion torque, trabecular bone microarchitecture and areal bone mineral density. Journal of the Mechanical Behavior of Biomedical Materials, 40, pp. 354-361, 2014. https://doi.org/10.1016/j. jmbbm.2014.09.009

[16] Ricci, W.M., Tornetta, P., Petteys, T., Gerlach, D., Cartner, J., Walker, Z. \& Russell, T.A., A comparison of screw insertion torque and pullout strength. Journal of Orthopaedic Trauma, 24(6), pp. 374-378, 2010. https://doi.org/10.1097/bot.0b013e3181c4a655

[17] Zanetti, E.M., Parametric analysis of orthopedic screws in relation to bone density. The Open Medical Informatics Journal, 3(1), pp. 19-26, 2009. https://doi. org/10.2174/1874431100903010019

[18] Zanetti, E.M. \& Bignardi, C., Structural analysis of skeletal body elements: Numerical and experimental methods. In Biomechanical systems technology (edited by Cornelius T Leondes (University of California, Los Angeles, USA), World Scientific Publishing, Vol. 3, 185-225, ISBN 978-981-270-983-7, 2009.

[19] Vitale, M.C., Chiesa, M., Coltellaro, F., Bignardi, C., Celozzi, M. \& Poggio, C., FEM analysis of different dental root canal-post systems in young permanent teeth. European Journal of Paediatric Dentistry, 9(3), pp. 111-117, 2008. 
[20] Taylor, D., Casolari, E. \& Bignardi, C., Predicting stress fractures using a probabilistic model of damage, repair and adaptation. Journal of Orthopaedic Research, 22, pp. 487-494, 2004. https://doi.org/10.1016/j.orthres.2003.08.022

[21] Zanetti, E. M. \& Bignardi, C. Mock-up in hip arthroplasty pre-operative planning. Acta of Bioengineering and Biomechanics, 15, pp. 123-128, 2013.

[22] Zanetti, E.M., Terzini, M., Mossa, L., Bignardi, C., Costa, P., Audenino, A. L. \& Vezzoni, A., A structural numerical model for the optimization of double pelvic osteotomy in the early treatment of canine hip dysplasia. Veterinary and Comparative Orthopaedics and Traumatology, 30(4), pp. 256-264, 2017. https://doi.org/10.3415/vcot-16-050065

[23] Terzini, M., Terzini, M., Zanetti, E.M., Audenino, A.L., Putame, G., Gastaldi, L., Pastorelli, S., Panero, E., Sard, A. \& Bignardi, C., Multibody modelling of ligamentous and bony stabilizers in the human elbow. Muscle Ligaments and Tendons Journal, 7, pp. 493-502, 2017. https://doi.org/10.32098/mltj.04.2017.03

[24] Zanetti, E.M., Ciaramella, S., Calì, M., Pascoletti, G., Martorelli, M., Asero, R. \& Watts, D.C., Modal analysis for implant stability assessment: Sensitivity of this methodology for different implant designs. Dental Materials, 34, pp. 1235-1245, 2018. https://doi. org/10.1016/j.dental.2018.05.016

[25] Aldieri, A., Terzini, M., Osella, G., Priola, A. M., Angeli, A., Veltri, A., Audenino, A. L. \& Bignardi, C., Osteoporotic hip fracture prediction: Is T-score-based criterion enough? A hip structural analysis-based model. Journal of Biomechanical Engineering, 140(11), Article no. 111004, 2018. https://doi.org/10.1115/1.4040586

[26] Pascoletti, G., Cianetti, F., Putame, G., Terzini, M. \& Zanetti, E.M., Numerical simulation of an intramedullary Elastic Nail: Expansion phase and load-bearing behavior. Frontiers in Bioengineering and Biotechnology, 6, p. 174, 2018. https://doi.org/10.3389/ fbioe.2018.00174

[27] Putzer, D., Nogler, M., Terzini, M., Mannara, R. \& Bignardi, C., A finite element analysis for a new short stem concept design with spherical bone interface for hip resurfacing. Journal of Mechanical Science and Technology, 9(3), pp. 923-935, 2018.

[28] Calì, M., Zanetti, E.M., Oliveri, S.M., Asero, R., Ciaramella, S., Martorelli, M. \& Bignardi, C., Influence of thread shape and inclination on the biomechanical behaviour of plateau implant systems. Dental Materials, 34(3), pp. 460-469, 2018. https://doi. org/10.1016/j.dental.2018.01.012

[29] Zanetti, E.M., Bignardi, C., Terzini, M., Putame, G. \& Audenino, A.L., A multibody model for the optimization of hip arthroplasty in relation to range of movement. Australasian Medical Journal, 11(10), pp. 486-491, 2018. https://doi.org/10.21767/ amj.2018.3444

[30] Pascoletti, G., Catelani, D., Conti, P., Cianetti, F. \& Zanetti, E.M., Multibody models for the analysis of a fall from height: Accident, suicide, or murder? Frontiers in Bioengineering and Biotechnology, 7, p. 419, 2019. https://doi.org/10.3389/fbioe.2019.00419

[31] Putame, G., Terzini, M., Bignardi, C., Beale, B., Hulse, D., Zanetti, E. \& Audenino, A., Surgical treatments for canine anterior cruciate ligament rupture: Assessing functional recovery through multibody comparative analysis. Frontiers in Bioengineering and Biotechnology, 7, pp. 1-11, 2019. https://doi.org/10.3389/fbioe.2019.00180

[32] Putame, G., Pascoletti, G., Franceschini, G., Dichio, G. \& Terzini, M., Prosthetic hip ROM from multibody software simulation. Proceeding of Annual International Conference of the IEEE Engineering in Medicine and Biology Society (EMBC), pp. 53865389, 2019. https://doi.org/10.1109/embc.2019.8856993 
[33] Pascoletti, G., Catelani, D., Conti, P., Cianetti, F. \& Zanetti, E.M., A multibody simulation of a human fall: Model creation and validation. Procedia Structural Integrity, 24, pp. 337-348, 2019. https://doi.org/10.1016/j.prostr.2020.02.031

[34] Terzini, M., Aldieri, A., Rinaudo, L., Osella, G., Audenino, A.L. \& Bignardi, C., Improving the hip fracture risk prediction through 2D finite element models from DXA images : Validation against 3D models. Frontiers in Bioengineering and Biotechnology, 7, 2019. https://doi.org/10.3389/fbioe.2019.00220

[35] Santoro, D., Nardi, M., Lasorella, F. \& Bignardi, C., Overlapping versus "kissing" plates in Femur: A FEM study. The Open Biomedical Engineering Journal, 13, pp. 94-101, 2019. https://doi.org/10.2174/1874120701913010094

[36] Putame, G., Pascoletti, G., Terzini, M., Zanetti, E.M. \& Audenino, A.L., Mechanical behavior of elastic self-locking nails for intramedullary fracture fixation: A numerical analysis of innovative nail designs. Frontiers in Bioengineering and Biotechnology, $\mathbf{8}$, pp. 1-10, 2020. https://doi.org/10.3389/fbioe.2020.00557

[37] Aldieri, A., Terzini, M., Audenino, A.L., Bignardi, C. \& Morbiducci, U., Combining shape and intensity dxa-based statistical approaches for osteoporotic hip fracture risk assessment. Computers in Biology and Medicine, 127, Article no. 104093, 2020. https:// doi.org/10.1016/j.compbiomed.2020.104093

[38] Terzini, M., Aldieri, A., Nurisso, S., De Nisco, G. \& Bignardi, C. Finite Element Modeling Application in Forensic Practice: A Periprosthetic Femoral Fracture Case Study. Frontiers in Bioengineering and Biotechnology, 8, p. 619, 2020. https://doi.org/10.3389/ fbioe.2020.00619

[39] Terzini, M., Di Pietro, A., Aprato, A., Artiaco, S., Massè, A. \& Bignardi, C., Are suprapectineal quadrilateral surface buttressing plates performances superior to traditional fixation? A finite element analysis. Applied Sciences, 11(2), p. 858, 2021. https://doi. org/10.3390/app11020858

[40] Bresciano, M., Schierano, G., Manzella, C., Screti, A., Bignardi, C. \& Preti, G., Retention of luting agents on implant abutments of different height and taper. Clinical Oral Implant Research, 16, pp. 594-598, 2005. https://doi.org/10.1111/j.16000501.2005.01159.x

[41] Zanetti, E.M., Crupi, V., Bignardi, C. \& Calderale, P.M., Radiograph-based femur morphing method. Medical \& Biological Engineering \& Computing, 43, pp. 181-188, 2005. https://doi.org/10.1007/bf02345952

[42] Menicucci, G., Ceruti, P., Barabino, E., Screti, A., Bignardi, C. \& Preti, G., A preliminary in vivo trial of load transfer in mandibular implant-retained overdentures anchored in 2 different ways: Allowing and counteracting free rotation. The International Journal of Prosthodontics, 19(6), pp. 574-576, 2006.

[43] Brianza, S.Z.M., D’amelio, P., Pugno, N., Delise, M., Bignardi, C. \& Isaia, G., Allometric scaling and biomechanical behavior of the bone tissue: An experimental intraspecific investigation. Bone, 40, pp. 1635-1642, 2007. https://doi.org/10.1016/j.bone.2007.02.013

[44] Brianza, S.Z.M., D’Amelio, P., Cerrato, M., Bignardi, C., Grimaldi, A., Pescarmona, G.P. \& Isaia, G., Dedicated image analysis software tool for the evaluation of the resorption activity of cultured osteoclasts. Journal of Imaging Science and Technology, 52(3), 030508-030508-9, 2008. https://doi.org/10.2352/j.imagingsci.technol. (2008)52:3(030508)

[45] D’Amelio, P., Rossi, P., Isaia, G., Lollino, N., Castoldi, F., Girardo, M., Dettoni, F., Sattin, F., Delise, M. \& Bignardi, C., Bone mineral density and singh index predict bone 
mechanical properties of human femur. Connective Tissue Research, 49, pp. 99-104, 2008. https://doi.org/10.1080/03008200801913940

[46] Zanetti, E.M., Bignardi, C. \& Audenino, A.L., Human pelvis loading rig for static and dynamic stress analysis. Acta of Bioengineering and Biomechanics, 14, pp. 61-66, 2012.

[47] Manzella, C., Burello, V., Bignardi, C., Carossa, S. \& Schierano, G., A method to improve passive fit of frameworks on implant-supported prostheses: An in vivo study. The International Journal of Prosthodontics, 26(6), pp. 577-579, 2013. https://doi. org/10.11607/ijp.3326

[48] Boero Baroncelli, A., Reif, U., Bignardi, C. \& Peirone, B., Effect of screw insertion torque on push-out and cantilever bending properties of five different angle-stable systems. Veterinary Surgery, 42(3), pp. 308-315, 2013. https://doi.org/10.1111/j.1532950x.2013.01088.x

[49] Marmotti, A., Bruzzone, M., Bonasia, D.E., Castoldi, F., Von Degerfeld, M.M., Bignardi, C., Mattia, S., Maiello, A., Rossi, R. \& Peretti, G.M., Autologous cartilage fragments in a composite scaffold for one stage osteochondral repair in a goat model. European Cells and Materials, 26, pp. 15-32, 2013. https://doi.org/10.22203/ecm.v026a02

[50] Massai, D., Cerino, G., Gallo, D., Pennella, F., Deriu, M.A., Rodriguez, A., Montevecchi, F.M., Bignardi, C., Audenino, A. \& Morbiducci, U., Bioreactors as engineering support to treat cardiac muscle and vascular disease. Journal of Healthcare Engineering, 4(3), pp.329-370, 2013. https://doi.org/10.1260/2040-2295.4.3.329

[51] Logozzo, S., Kilpelä, A., Mäkynen, A., Zanetti, E.M. \& Franceschini, G., Recent advances in dental optics - Part II: Experimental tests for a new intraoral scanner. Optics and Lasers in Engineering, 54, pp. 187-196, 2014. https://doi.org/10.1016/j. optlaseng.2013.07.024

[52] Aimetti, M., Mariani, G.M., Ferrarotti, F., Ercoli, E., Audagna, M., Bignardi, C. \& Romano, F., Osseous resective surgery with and without fibre retention technique in the treatment of shallow intrabony defects: A split-mouth randomized clinical trial. Journal of Clinical Periodontology, 42(2), pp. 182-189, 2015. https://doi.org/10.1111/ jcpe. 12343

[53] Manzella, C., Bignardi, C., Burello, V., Carossa, S. \& Schierano, G., Method to improve passive fit of frameworks on implant-supported prostheses: An in vitro study. The Journal of Prosthetic Dentistry, 116(1), pp. 52-58, 2016. https://doi.org/10.1016/j.prosdent.2016.01.006

[54] Falvo D’Urso Labate, G., Baino, F., Terzini, M., Audenino, A., Vitale Brovarone, C., Segers, P., Quarto, R. \& Catapano, G., Bone structural similarity score: A multiparametric tool to match properties of biomimetic bone substitutes with their target tissues. Journal of Applied Biomaterials \& Functional Materials, 14, pp. e277-e289, 2016. https://doi.org/10.5301/jabfm.5000283

[55] Zanetti, E.M., Aldieri, A., Terzini, M., Calì, M., Franceschini, G. \& Bignardi, C., Additively manufactured custom load-bearing implantable devices: Grounds for cautions. Australasian Medical Journal, 10(8), pp. 694-700, 2017. https://doi.org/10.21767/ amj.2017.3093

[56] Manavella, V., Romano, F., Garrone, F., Terzini, M., Bignardi, C. \& Aimetti, M., A novel image processing technique for 3D volumetric analysis of severely resorbed alveolar sockets with CBCT. Minerva Stomatologica., 66(3), pp. 81-90, 2017. 
[57] Bignardi, C., Terzini, M., Audenino, A.L., Massai, D., Aprato, A., Massè, A., Costa, P. \& Zanetti, E.M., Pelvic manipulator for fractures reduction. Journal of Mechanical Science and Technology, 9, pp. 570-580, 2018.

[58] Bignardi, C., Zanetti, E.M., Terzini, M., Ciccola, A.R., Schierano, G. \& Audenino, A.L., Reliability, learnability and efficiency of two tools for cement crowns retrieval in dentistry. The Open Biomedical Engineering Journal, 12(1), pp. 27-35, 2018. https:// doi.org/10.2174/1874120701812010027

[59] Bellia, E., Boggione, L., Terzini, M., Manzella, C. \& Menicucci, G., Immediate loading of mandibular overdentures retained by two mini-implants: A case series preliminary report. The International Journal of Prosthodontics, 31, pp. 558-564, 2018. https://doi. org/10.11607/ijp.5589

[60] Aimetti, M., Manavella, V., Corano, L., Ercoli, E., Bignardi, C. \& Romano, F. Threedimensional analysis of bone remodeling following ridge augmentation of compromised extraction sockets in periodontitis patients: A randomized controlled study. Clinical Oral Implants Research, 29, pp. 202-214, 2018. https://doi.org/10.1111/clr.13099

[61] Manavella, V., Romano, F., Corano, L., Bignardi, C. \& Aimetti, M., Three-dimensional volumetric changes in severely resorbed alveolar sockets after ridge augmentation with bovine-derived xenograft and resorbable barrier: A preliminary study on CBCT imaging. Int J Oral Maxillofac Implants, 33(2), pp. 373-382, 2018. https://doi.org/10.11607/ jomi.5684

[62] Zanetti, E.M., Pascoletti, G., Calì, M., Bignardi, C. \& Franceschini, G., Clinical assessment of dental implant stability during follow-up: What is actually measured, and perspectives. Biosensors (Basel), 8(3), pii: E68, 2018. https://doi.org/10.3390/bios8030068

[63] Pascoletti, G., Dichio, G., Marmotti, A., Baroncelli, A.B., Costa, P., Lugas, A.T. \& Serino, G., A novel technique for testing osteointegration in load-bearing conditions. WIT Transactions on Engineering Sciences, 124, pp. 187-194, 2019. https://doi. org/10.2495/mc190181

[64] Corapi, D., Morettini, G., Pascoletti, G. \& Zitelli, C., Characterization of a polylactic acid (PLA) produced by Fused Deposition Modeling (FDM) technology. Procedia Structural Integrity, 24, pp. 289-295, 2019. https://doi.org/10.1016/j.prostr.2020.02.026

[65] Giorgi, M., Sotiriou, V., Fanchini, N., Conigliaro, S., Bignardi, C., Nowlan, N.C. \& Dall'Ara, E., Prenatal growth map of the mouse knee joint by means of deformable registration technique. PLoS One, 14(1), p. e0197947, 2019. https://doi.org/10.1371/ journal.pone.0197947

[66] Panero, E., Gastaldi, L., Terzini, M., Bignardi, C., Sard, A. \& Pastorelli, S., Biomechanical role and motion contribution of ligaments and bony constraints in the elbow stability: A preliminary study. Bioengineering, 6(3), pp. 68-79, 2019. https://doi. org/10.3390/bioengineering6030068

[67] Pascoletti, G., Pressanto, M.C., Putame, G., Terzini, M., Franceschini, G. \& Zanetti, E.M., Data from cyclic tensile tests on sutured organs to evaluate creep behaviour, distraction, and residual thread strength. Data in Brief, 30, p. 105644, 2020. https://doi. org/10.1016/j.dib.2020.105644

[68] Fragomeni, G., Terzini, M., Comite, A. \& Catapano, G., The maximal pore size of hydrophobic microporous membranes does not fully characterize the resistance to plasma breakthrough of membrane devices for extracorporeal blood oxygenation. Frontiers in Bioengineering and Biotechnology, 7, pp. 1-9, 2020. https://doi.org/10.3389/fbioe.2019.00461

[69] Calì, M., Pascoletti, G., Gaeta, M., Milazzo, G. \& Ambu, R., A new generation of biocomposite thermoplastic filaments for a more sustainable design of parts manufactured by FDM. Applied Sciences, 10(17), p. 5852, 2020. https://doi.org/10.3390/app10175852 
[70] Calì, M., Pascoletti, G., Gaeta, M., Milazzo, G. \& Ambu, R., New filaments with natural fillers for FDM 3D printing and their applications in biomedical field. Procedia Manufacturing, 51, pp. 698-703, 2020. https://doi.org/10.1016/j.promfg.2020.10.098

[71] Dichio, G., Calì, M., Terzini, M., Putame, G., Zanetti, E.M., Costa, P. \& Audenino, A.L., Engineering and manufacturing of a dynamizable fracture fixation device system. Applied Sciences, 10(19), p. 6844, 2020. https://doi.org/10.3390/app10196844

[72] Lugas, A.T., Terzini, M., Zanetti, E.M., Schierano, G., Manzella, C., Baldi, D., Bignardi, C. \& Audenino, A.L., In vitro impact testing to simulate implant-supported prosthesis retrievability in clinical practice: Influence of cement and abutment geometry. Materials (Basel), 13(7), p. 1749, 2020. https://doi.org/10.3390/ma13071749

[73] Lugas, A.T., Terzini, M., Zanetti, E.M., Schierano, G., Manzella, C., Baldi, D., Bignardi, C. \& Audenino, A.L., In vitro simulation of dental implant bridges removal: Influence of luting agent and abutments geometry on retrievability. Materials (Basel), 13(12), p. 2747, 2020. https://doi.org/10.3390/ma13122797

[74] Pascoletti, G., Pressanto, M.C., Putame, G., Terzini, M., Audenino, A.L. \& Zanetti, E.M., On-site testing of sutured organs: An experimental set up to cyclically tighten sutures. Journal of the Mechanical Behavior of Biomedical Materials, 109, p. 103803, 2020. https://doi.org/10.1016/j.jmbbm.2020.103803

[75] Pascoletti, G., Pressanto, M.C., Putame, G., Terzini, M., Franceschini, G. \& Zanetti, E.M., Design of a loading system for cyclic test on sutured organs. MethodsX, 7(7), p. 100988, 2020. https://doi.org/10.1016/j.mex.2020.100988

[76] Peluccio, M.S., Bignardi, C., Lombardo, S., Montevecchi, F.M. \& Carossa, S., Comparative study of nanomechanical properties of cements used in teeth restoration. Journal of Physics: Condensed Matter, 19, p. 395003, 2007. https://doi.org/10.1088/09538984/19/39/395003

[77] Bhushan, B., Galasso, B., Bignardi, C., Nguyen, C.V., Dai, L. \& Qu, L., Adhesion, friction and wear on nanoscale of MWNT Tips and SWNT and MWNT arrays. Nanotechnology, 19, p. 125702, 2008. https://doi.org/10.1088/0957-4484/19/12/125702

[78] Bignardi, C., Petraroli, M. \& Pugno, N.M., Nanoindentation on Conch Shells of Gastropoda and Bivalvia Molluscs reveal anisotropic evolution against external attacks. Journal of Nanoscience and Nanotechnology, 10(10), pp. 6453-6460, 2010. https://doi. org/10.1166/jnn.2010.2626

[79] Zanetti, E.M., Perrini, M., Bignardi, C. \& Audenino, A.L., Bladder tissue passive response to monotonic and cyclic loading. Biorheology, 49, pp. 49-63, 2012. https:// doi.org/10.3233/bir-2012-0604

[80] Canavese, G., Stassi, S., Stralla, M., Bignardi, C. \& Pirri, C.F., Stretchable and conformable metal-polymer piezoresistive hybrid system. Sensors and Actuators A: Physical, 186(1), pp. 191-197, 2012. https://doi.org/10.1016/j.sna.2012.01.037

[81] Zanetti, E.M., Bignardi, C., Franceschini, G. \& Audenino, A.L., Amateur football pitches: Mechanical properties of the natural ground and of different artificial turf infills and their biomechanical implications. Journal of Sports Sciences, 31(7), pp. 767-778, 2013. https://doi.org/10.1080/02640414.2012.750005

[82] Terzini, M., Bignardi, C., Castagnoli, C., Cambieri, I., Zanetti, E.M. \& Audenino, A.L., Ex vivo dermis mechanical behavior in relation to decellularization treatment length. The Open Biomedical Engineering Journal, 10, pp. 34-42, 2016. https://doi. org/10.2174/1874120701610010034

[83] Terzini, M., Bignardi, C., Castagnoli, C., Cambieri, I., Zanetti, E.M. \& Audenino, A.L., Dermis mechanical behaviour after different cell removal treatments. Medi- 
cal Engineering \& Physics, 38, pp. 862-869, 2016. https://doi.org/10.1016/j.medengphy.2016.02.012

[84] Aldieri, A., Terzini, M., Bignardi, C., Zanetti, E.M. \& Audenino, A.L., Implementation and validation of constitutive relations for human dermis mechanical response. Medical \& Biological Engineering \& Computing, 56(11), pp. 2083-2093, 2018. https://doi. org/10.1007/s11517-018-1843-y

[85] O’Neill, M., Mala, R., Cafiso, D., Bignardi, C. \& Taylor, D., Repair and remodelling in the shells of the limpet Patella vulgata. Journal of Royal Society Interface, 15(145), pii. 20180299, 2018. https://doi.org/10.1098/rsif.2018.0299

[86] Terzini, M., Aldieri, A., Zanetti, E.M., Massai, D., Audenino, A.L. \& Bignardi, C., Native human dermis versus human acellular dermal matrix: A comparison of biaxial mechanical properties. Australasian Medical Journal, 11(8), pp. 434-442, 2018. https://doi.org/10.21767/amj.2018.3487

[87] Zanetti, E.M., Serino, G., Audenino, A.L. \& Bignardi, C., Artificial turf pitches and synthetic grass: Macro and nano friction properties. International Journal of Mechanical Engineering and Technology, 9(13), pp. 832-839, 2018.

[88] Fiume, E., Serino, G., Bignardi, C., Verné, E. \& Baino, F., Bread-derived bioactive porous scaffolds: An innovative and sustainable approach to bone tissue engineering. Molecules, 24, p. 2954, 2019. https://doi.org/10.3390/molecules24162954

[89] Pascoletti, G., Di Nardo, M., Fragomeni, G., Barbato, V., Capriglione, T., Gualtieri, R., Talevi, R., Catapano, G. \& Zanetti, E.M., Dynamic characterization of the biomechanical behaviour of bovine ovarian cortical tissue and its short-term effect on ovarian tissue and follicles. Materials (Basel), 13(17), p. 3759, 2020. https://doi.org/10.3390/ ma13173759

[90] Fiume, E., Serino, G., Bignardi, C., Verné, E. \& Baino, F., Sintering behavior of a sixoxide silicate bioactive glass for scaffold manufacturing. Applied Sciences, 10, p. 8279, 2020. https://doi.org/10.3390/app10228279

[91] Serino, G., Gusmini, M., Audenino, A.L., Bergamasco, G., Ieropoli, O. \& Bignardi, C., Multiscale characterization of isotropic pyrolytic carbon used for mechanical heart valve production. Processes, 9, p. 338, 2021. https://doi.org/10.3390/pr9020338

[92] Fiume, E., Schiavi, A., Orlygsson, G., Bignardi, C., Verné, E. \& Baino, F., Comprehensive assessment of bioactive glass and glass-ceramic scaffold permeability: Experimental measurements by pressure wave drop, modelling and computed tomography-based analysis. Acta Biomaterialia, 119, pp. 405-418, 2021. https://doi.org/10.1016/j.actbio.2020.10.027

[93] Putame, G., Terzini, M., Carbonaro, D., Pisani, G., Serino, G., Di Meglio, F., Castaldo, C. \& Massai, D., Application of 3D printing technology for design and manufacturing of customized components for a mechanical stretching bioreactor. J. Healthc. Eng., Article ID3957931, 2019. https://doi.org/10.1155/2019/3957931

[94] Belviso, I., Romano, V., Sacco, A.M., Ricci, G., Massai, D., Cammarota, M., Catizone, A., Schiraldi, C., Nurzynska, D., Terzini, M., Aldieri, A., Serino, G., Schonauer, F., Sirico, F., Andrea, F.D., Montagnani, S., Di Meglio, F. \& Castaldo, C., Decellularized human dermal matrix as a biological scaffold for cardiac repair and regeneration. Frontiers in Bioengineering and Biotechnology, 8, p. 229, 2020. https://doi.org/10.3389/ fbioe. 2020.00229 